Simba and Thai (2018)

Journal of Small Business Management

\title{
Advancing entrepreneurial leadership as a practice in MSME management and development
}

\begin{abstract}
Since its inception, two decades ago, entrepreneurial leadership still has a long way to go as a practice in MSME management and development. Considering that MSMEs are small-sized enterprises trading in multiple business sectors, management and business development issues are unavoidable. As such, their business methods would require nuanced paradigms and applied means for addressing these issues. Drawing upon the theory of entrepreneurial leadership, this article explores management and business development strategies applicable to MSMEs. Its emphasis on the mutual cross-fertilisation between entrepreneurship and leadership as a means for enabling fresh MSME management and development strategies, underscores its contributions.
\end{abstract}

Key words: entrepreneurial leadership, MSMEs, small business management, business development

\section{Introduction}

Existing entrepreneurship paradigms (see for example: Antoncic, 2003; Block and MacMillan, 1993; Covin and Slevin, 1991; Dess et al., 2003; Ireland et al., 2009; Kuratko et al., 2004) and leadership theories (e.g. McCarthy, 2014; Quist, 2009; Yukl, 1999) originate from studies that have only focussed on large and more established organisations (Burns, 2016; Franco and Matos, 2013). Therefore, utilising such constructs to explore management and business development in microsmall and medium enterprise (MSME) would be problematic, due to several reasons. To start with, their sizes, resource bases and experiences vary widely, plus MSMEs have a high liability due to their newness (Garnsey, 1998; Stinchcombe, 1965) in the multiple markets they operate, as they are often spread across several business sectors (Bonger and Chileshe, 2013; Reeg, 2013). 
Simba and Thai (2018)

Journal of Small Business Management

In that regard, the application of entrepreneurial leadership to explore the management and business development approaches in MSMEs, this article promotes, perhaps offer new insights and direction (Leitch and Volery, 2017; Leitch et al., 2013; Ireland et al., 2003). Entrepreneurial leadership embodies strategic and process thinking (Hitt and Ireland, 2005), processual (Kraus et al., 2007), and rationality (Sklaveniti, 2017) as core components of its multi-dimensional constructs. On the basis of the combined effects of these constructs, there is a case to argue for its (entrepreneurial leadership's) suitability in orchestrating effective management and business development methods in small businesses (Freiling, 2007). Equally, Matthews (2017) emphasised that an eclectic approach to entrepreneurial leadership which draws on the key processes of other perspectives presents a holistic view of its effectiveness. As such, utilising entrepreneurial leadership and its components as a means for delineating MSME management and business development, as this article proposes to do, would underscore its value to these small businesses.

To appreciate the value of entrepreneurial leadership in MSMEs within their entrepreneurial context (Matthews, 2017), the following two overarching questions, that characterise entrepreneurship and leadership in small businesses, were used to guide research in this article. (i) In which ways would entrepreneurial leadership enable practical and effective ways of dealing with management and development issues in MSMEs within the multiple markets they operate? (ii) Which specific functional and self-competencies their owner-managers/leaders would need to develop for their ventures to succeed in their multiple markets? By addressing these fundamental questions, the article responds to a growing chorus of voices calling for scholarly works that focus on understanding the elements that comprise entrepreneurial leadership. 
Simba and Thai (2018)

Journal of Small Business Management

One such call for research was initiated by Kuratko (2007) in his editorial note for a special issue on Entrepreneurial Leadership in the $21^{\text {st }}$ Century. His note to researchers expressed the importance of considering entrepreneurial leadership in today's new ventures. Kuratko was unambiguously clear that "entrepreneurial leadership is becoming a global necessity and the more we can understand the elements that comprise this concept, the more we can advance the concept itself' $(2007$, p. 8). His calls for advancing entrepreneurial leadership were also echoed by Leith and Volery (2017) who stressed that there is a need to take into account the cognitive, interpersonal and social richness of leadership in SMEs and to come to grips with processes that would account for outcomes. Both Kuratko's (2007); Leith and Volery's (2017) calls, for exploring and understanding entrepreneurial leadership, though a decade apart, demonstrate the urgency that is now needed to seriously reflect on the value for advancing the concept in the study of small businesses.

Research that has been carried out, hitherto, seems to recognise the impact of entrepreneurship and leadership as crucial factors in the success or failure of small entrepreneurial firms, and has implications for our understanding of their business methods, viability and growth (Harrison and Leith, 2018; Ng and Kee, 2018; Leitch et al., 2013; Renko et al., 2015). In the presence of such evidence and the economic development impact often associated with entrepreneurship (Acs and Storey, 2004; Siddiqui and Jan, 2017; Wennekers and Thurik 1999), it is hoped that this article will chart a practical and effective framework for business management. The framework the article offers is presented as an instructive tool for use in reviewing entrepreneurship in MSME and for explaining complementary leadership styles their owner-managers/leaders may consider adopting in their preferred entrepreneurial contexts. This is important given that the multiple markets they are involved may require refined management methods complemented by a dynamic approach to business development. 
Simba and Thai (2018)

Journal of Small Business Management

\section{Theoretical background}

What are the theoretical grounds that would justify focusing upon MSME management and business development? At face value, one would look to entrepreneurial leadership for new insights and direction (Fernald et al., 2005; Kuratko, 2007; Leitch and Volery, 2017). But, a closer look at entrepreneurial leadership's multi-dimensional constructs may, in fact, further provide nuanced management and business development methods for these enterprises.

Since its inception in the early 90s (Gartner et al., 1992; Harrison and Leitch, 1994), entrepreneurial leadership has been employed as a mechanism for diagnosing management, development, and growth-related issues within small businesses, in general. For example; Mupunda's (2007) empirical paper framed entrepreneurial leadership as a factor in the growth and development of indigenous small enterprises in Tanzania and South Australia. Likewise, Koryak's et al. (2015) literature-based study showed how entrepreneurial leadership influenced growth in small-to-medium enterprises (SMEs) by building dynamic capabilities. Furthermore, Jones and Crompton (2009) studied several SMEs based in the Northwest of England. They explored ideas associated with entrepreneurial leadership in the face of changing economic conditions and concluded that in such circumstances entrepreneurial leadership is crucial. Jones and Crompton (2009) further clarified that encouraging an entrepreneurial mind-set in SMEs requires a combination of entrepreneurial and leadership capabilities. Similarly, Sklaveniti (2017) offered theoretical conceptions for advancing entrepreneurial leadership in SME ventures. Sklaveniti's (2017) theoretical propositions comprised four processes namely: creativity genesis, creativity enactment, direction genesis, and direction enactment. Sklaveniti underscored the four processes as essential for understanding the emergence of a new venture from a lived perspective. 
Simba and Thai (2018)

Journal of Small Business Management

Considering the above, the idea of adopting entrepreneurial leadership philosophies in the study of MSMEs may well provide applied and meaningful ways for isolating operational complications (El-Namaki, 1992; Timmons, 1978) that often conspire to influence their management and development. In that respect, there is a point in applying an entrepreneurial leadership frame to decipher management and business development enigmas in MSMEs.

\section{The evolution of entrepreneurship}

Entrepreneurship is a broad phenomenon that has got many facets. According to Steyaert and Hjorth (2003, p.5) "there are many entrepreneurships in terms of focus, definitions, scope and paradigms". One reason for the existence of many different definitions of entrepreneurship is that, it is studied in several different disciplines including: economics, psychology, sociology, and management (Nielsen et al., 2017). This study takes advantage of the rich multidisciplinary orientation of entrepreneurship and it aligns with Gibb's (2000) comprehensive description of the concept. Gibb stressed that entrepreneurship "relates to ways in which people, in all kinds of organisations behave in order to cope with and take advantage of uncertainty and complexity and how in turn this becomes embodied in: ways of doing things; ways of feeling things; ways of communicating things and ways of learning things" (2000, p.13). Perhaps, Gibb's view of entrepreneurship was a signal of a shift from simply concentrating on the act of new venture creation (Parker, 2014) or just the activities of the entrepreneur (Kirzner, 1973; Schumpeter, 1934) to focussing on bringing together important aspects of management and business development (Bridge, 2017; Bridge and O’Neill, 2018; Harrison and Leitch, 2018). Consistent with this, Kuratko (2014) was conclusive, stating that entrepreneurship is more than the mere creation of a new venture. The characteristics of opportunity-seeking, taking risks beyond security and having the tenacity to push an idea through to reality combine into a special perspective, Kuratko (2018) described as entrepreneurial mind-set. 
Simba and Thai (2018)

Journal of Small Business Management

According to Kuratko and Morris (2013), this special perspective has become the standard by which leadership is measured. Similarly, Stevenson et al. (1989) regarded entrepreneurship as an approach to management. In this view, Stevenson and others highlighted 'promoters' as individuals whose strategic direction is mainly driven by the perception of opportunity and 'trustees' as individuals who are driven by the resources they currently hold. In other scholarly works, this view was extended to emphasise both entrepreneurial and leadership skills as pivotal in the development of small businesses (Bridge, 2017; Fernald et al., 2005; Siddiqui and Jan, 2017).

Furthermore, entrepreneurship was fully described in the Education and Entrepreneurship Plan for Northern Ireland in 2003. In this 2003 plan for entrepreneurship in Northern Ireland, the concept was presented as the ability of an individual who possess a range of essential skills and attributes to make a unique, innovative and creative contribution in the world of work, whether in employment or self-employed. This conceptualisation of entrepreneurship points to evidence of a mutual cross-fertilisation with leadership. It also indicates that it is unavoidable that, when describing entrepreneurship using the macro-level environment and institutional forces, and micro-level behavioural and cognitive process (Breslin, 2011), one can easily stray into aspects of leadership. That should not be treated as a problem per se, but rather it should be welcomed as it advances the study of entrepreneurship and leadership, particularly in entrepreneurial firms. Given the multi-level nature of the business routines (Bridge and O’Neill, 2018) MSMEs require within the multiple sectors they spread their operations, an approach that connects entrepreneurship with leadership features can be decisive. 
Simba and Thai (2018)

Journal of Small Business Management

Indeed, because entrepreneurship recognises the interaction between individuals, institutional forces and the macro-environment (Bridge, 2017; Bridge and O’Neill, 2018), such a consequential link to leadership would undoubtedly provide the management and development base MSMEs need within their entrepreneurial context. In view of the foregoing discussion, a possible conclusion that can be drawn from this is that, entrepreneurship benefits from leadership theories because of their considered influence and process emphasis.

\section{Leadership}

In management studies and psychology, leadership has been subjected to extensive research for almost a century, involving thousands of empirical and conceptual studies (Leitch and Volery 2017, Western, 2013, Yukl and Chavez, 2002). Nonetheless, this intense scrutiny has only resulted in many different conceptualisations of leadership that do not seem to have a unifying position (see for example: Bass and Stogdill, 1990; Burns, 2014; Northouse, 2018; Western, 2013; Yukl and Chavez, 2002). As much as these ideas about leadership do not seem to converge on one common definition of leadership, the various angles they focus on have been largely insightful especially the ideas of contextual, transformational, and transactional leadership (Osborn et al., 2002; Yukl, 2012). From these well-established leadership concepts, two important variables including individual and organisational capabilities have surfaced. The analysis of the interplay between these variables (Hutchinson, 2017; Osborn and Marion, 2009) has arguably led to the realisation that entrepreneurship and leadership have some commonalities (Gartner et al., 1992; Harrison and Leitch, 1994; Leith et al., 2009; Harrison and Leith, 2018). Consequently, this has resulted in the establishment of a new concept -entrepreneurial leadership, which is progressively gaining prominence in studying entrepreneurial firms. 
Simba and Thai (2018)

Journal of Small Business Management

It is increasingly being recognised in the management and leadership literature that effective leadership is not universal, but it is dependent upon a wide variety of environmental (culture, economic, industry setting, etc.) and organizational (strategy, size, technology, structure) conditions (Northouse, 2018; Shamir and Howell, 1999; Lord et al., 2001). There is therefore logic in claiming that the meaning and importance attached to numerous leadership dimensions varies by context (Osborn et al, 2002).

Contexts can be so complex that no single microscopic view can be sufficiently detailed and comprehensive to suggest a singular productive view of leadership or leadership effectiveness (Osborn and Marion, 2009). In that regard, there is a great need for considering the mutual crossfertilisation of a series of theories. To this end, this article endeavours to further advance the idea of entrepreneurial leadership which draws on the theories of entrepreneurship and leadership.

\section{Entrepreneurship \& leadership mutual cross-fertilisation}

Entrepreneurial leadership is a concept that is very much in its infancy (Leith $e t$ al., 2013). It exists at the intersection or cross roads of entrepreneurship and leadership (Cogliser and Brigham 2004; International Council for Small Business (ICSB), 2015; Renko et al., 2015; Tarabishy et al., 2005). Moreover, it draws attention to enterprising individuals, even when its outcomes are measured at firm level (McClelland, 1961; Renko et al., 2015; Skodvin and Andresen, 2006). Leitch and Volery (2017) positioned entrepreneurial leadership as a phenomenon located at the nexus between the leadership and entrepreneurship fields. This may suggest that both domains benefit from mutual cross-fertilisation. Given its distinctive characteristics and origins, various academics (see Table 1) that have attempted to describe entrepreneurial leadership have acknowledged that it encompasses attributes such as personality, style, business management, internal operations and external business conditions. 
Simba and Thai (2018)

Journal of Small Business Management

Table 1: A sample of existing conceptualisations of entrepreneurial leadership

Cunningham Entrepreneurial leadership involves setting clear goals, creating and Lischeron opportunities, empowering people, preserving organisational intimacy, and (1991) developing a human resource system.

Ireland et al. Entrepreneurial leadership entails the ability to influence others to manage 2003 resources strategically in order to emphasize both opportunity-seeking and advantage-seeking behaviours.

Thornberry Leadership requires passion, vision, focus, and the ability to inspire others. (2006) Entrepreneurial leadership requires all these, plus a mind-set and skill set that helps entrepreneurial leaders identify, develop, and capture new business opportunities.

Darling et al. Entrepreneurial leadership can generally be thought of as leading, through 2007) direct involvement, a process that creates value for organizational stakeholders by bringing together a unique innovation and package of resources to respond to a recognized opportunity.

Goossen and Entrepreneurial leadership is the type of leadership which provides for the Stevens (2013) scenarios where committed followers are gathered to be led by the vision of the leader towards finding new opportunities and utilising them for sustainable success and value for the organisation.

Renko et al.2015 Entrepreneurial leadership entails influencing and directing the performance of group members toward the achievement of organizational goals that involve recognizing and exploiting entrepreneurial opportunities.

Fontana and Entrepreneurial leadership is about influencing others toward a goal Musa (2017) through effective communication to recognize opportunity and share a vision about future possibilities that organizations could exploit to sustain competitiveness.

Adapted from Leitch and Volery (2017) and Renko et al., 2015 plus authors' ideas

Some have focussed on entrepreneurial leadership from a purely human empowerment and management perspective (Nicholson, 1998). Although Vecchio (2003) aligned his views with the human empowerment and management school of thought, he did not see anything distinctive about entrepreneurial leadership. Leitch and Volery (2017, p. 148) elaborated on this view about entrepreneurial leadership and stressed that, "it is simply a type of leadership that occurs in a specific setting, such as emerging organisations or small, fast-growing businesses”. 
Simba and Thai (2018)

Journal of Small Business Management

Consistent with these ideas, the ICSB (2015) commented that entrepreneurial leadership is a "style rather than a theory and it "fits" well within an all echelons approach to strategic leadership". The ideas endorsed by scholars and ICSB cited above, perhaps suggest that entrepreneurial leadership may just as well be another form of leadership. However, notwithstanding these well-established scholarly views in the literature, other scholars took a holistic and complementary approach in their conceptualisation of entrepreneurial leadership. Those who took this approach marked a departure from the one-sided view of entrepreneurial leadership, and emphasised the fusion of both entrepreneurship and leadership constructs (see for example: Cogliser and Brigham 2004; Tarabishy et al., 2005). This notion of looking at entrepreneurship and leadership as an intertwined paradigm was also advanced elsewhere.

In the scholarly works of Covin and Slevin (1988); Gupta et al. (2004); Leith et al. (2013); Renko et al. (2015); Stevenson and Jarillo (1986) entrepreneurial leadership was described as a synthesis of three key concepts including entrepreneurship, entrepreneurial orientation and management with leadership. In addition, Freiling (2007) offered theoretical perspectives comprising system renewal (Johnson et al., 2014), system exploitation (Tidd and Bessant, 2014), and system protection (Slack and Lewis, 2008) as anchor points that are particularly relevant in growing and managing small businesses. So, by combining Freiling's (2007) integrated perspectives on entrepreneurial leadership with the previous philosophies that advocated for the fusion of entrepreneurship and leadership constructs, it is unequivocal that management and the business development activities undertaken in small businesses stand to benefit from entrepreneurial leadership's functional and processual methods. 
Simba and Thai (2018)

Journal of Small Business Management

On the basis of the forgoing debate on what constitutes entrepreneurial leadership, this study assumes a pragmatic approach in its delineation. It aligns with Leitch and Volery's (2017) school of thought that entrepreneurial leadership is about role and behaviour defined by interaction in specific contexts. The emphasis is on the more dynamic view of entrepreneurial leadership including leadership development (Leitch et al. 2009). This view also extends entrepreneurial leadership as a concept that guides attention to those very parts of leadership that enhance entrepreneurial behaviours among followers (Carsrud et al., 2018). Consequently, increasing entrepreneurial intensity -a precursor for commercial success in dynamic markets (Siddiqui and Jan, 2017). It can be argued that a CEO's transformational leadership style shapes corporate behaviour, that impacts a firms' engagement in entrepreneurship activities (Ling et al., 2008), can lead to corporate level entrepreneurship (Burns, 2016).

Notwithstanding this well-established view above, it's worth highlighting what differentiates entrepreneurial leadership from transformational leadership for example. Entrepreneurial leadership benefits from the mutual cross-fertilisation between entrepreneurship and leadership (Carsrud et al., 2018; Hutchinson and Leitch, 2018). Arguably, its multi-dimensional orientation can enable a firm to enhance opportunity recognition and exploitation as their leaders and employees would be engaged in opportunity-focused behaviours (Hatem, 2018). Such a distinction when debating small business management and development is important as it provides greater concentration on the functions and activities that matter for entrepreneurial action (Bell and Whittington, 2018; Carsrud et al., 2018, Kuratko, 2018). 
Simba and Thai (2018)

Journal of Small Business Management

Perhaps, credit is due to those scholarly works in the literature that have endorsed the view that entrepreneurial leadership has more to do with individual capabilities (e.g. Hansson and Mønsted, 2008; Kansikas et al., 2012; Skodvin and Andresen, 2006), as well as business enterprise skills including leading, directing, and providing scope (Hutchinson, 2017; Harrison and Leitch, 2018; Klaus et al., 2007; Tarabishy et al., 2005). Their vision about entrepreneurial leadership may have paved the way for other scholars to seriously consider it as a new method in the management and development of MSMEs.

\section{The nature and characteristics of MSMEs}

MSMEs are categorised as small-sized enterprises (Garnsey, 1998), that have limited liability (Stinchcombe, 1965) and are often established with a limited resources base (Wiklund et al., 2009). The liability of smallness is known to be inherent among MSMEs (Lall, 2000; Roxas, et al., 2000). Another common characteristic of these enterprises is concerned with the way their ownermanagers shape their organisation, management and development (Freiling, 2007). These individuals often imprint their DNA and they directly influence strategy development and the direction of the ventures (Burns, 2010). Such characterisation implies that the management and business development methods in many small businesses reflect, to a large extent, the attributes of their leader(s), owner or founding figure (Storey, 1994; Beaver, 2002).

In the context of MSMEs the business model they seem to follow is distinctive and often complex. According to Reeg (2013a) they operate in a wide range of business sectors. This unorthodox enterprise behaviour displayed through their business operations was effusively explained fully in Bonger and Chileshe (2013). Bonger and Chileshe clarified that MSMEs engage in many business activities across several sectors. This demonstrates the heterogeneity and sophisticated business approaches MSMEs often adopt. They engage in businesses ranging from petty traders and artisans to high-end, technologically advanced and specialised manufacturing units (Reeg, 2013a). 
Simba and Thai (2018)

Journal of Small Business Management

Such enterprising behaviour can be described as context-motivated. Quite clearly, their business posture is shaped by the socio-economic conditions militating their environment (Kibera, 2000). If we take, for instance, the developing and emerging economy context, MSMEs are predominantly active within the informal sector (Reeg, 2015). In such a market structure, they turn to adapt their business activities as a response.

From a developing, emerging, and even advanced country context, MSMEs have for far too long been a vital segment of their overall economies (Berry et al., 2002; Maxwell et al., 2007). The United Nations Development Programme (UNDP) (2004) reported that MSMEs account for, by far, the great majority of enterprises globally with the highest capital/employment ratio and they provide income to a broad layer of the world population. Given their economic significance (see for example: Acs and Storey, 2004; Alvarez et al., 2011; Audretsch and Keilbach, 2004; Bolton, 1971) an understanding of what constitutes their existence, nature and characteristics alongside their management and development process may be justified.

Although understanding the management and business development activities of MSMEs has become a necessity, there are noteworthy issues. For example, the criteria used to define MSMEs vary widely from country to country. Various and complex methods for defining MSMEs have been reported in the literature and these have often included, the number of employees, turnover, capital investments, nature of activity and combinations (Reeg, 2015; Saxena and Jagota, 2015) as well as their business strategies and approaches to resource management (Maxwell et al., 2007). This has been further complicated by the wider umbrella terms used to categorise them. The broader categories often used include micro and small-sized enterprises (MSEs) and micro, small and medium-sized enterprises (MSMEs) (Reeg, 2015; United States Agency for International Development (USAID), 2007). 
Simba and Thai (2018)

Journal of Small Business Management

As much as the debate about what constitutes a typical MSME is worth pursuing, the disparity with respect to their competing classifications will not be resolved in this article. But, from the brief characterisation of these unique enterprises, it is clear that they are small in size and their reported business models suggest a tendency of spreading operational activities across several business sectors in anticipation for high returns and growth. It would therefore be expected that given their size, newness, and limited resources base it would be difficult for them to sidestep management and development related issues in their operations. As such, by applying the principles of entrepreneurial leadership it may be possible to fully diagnose and map out a new management and business development path for MSMEs.

\section{Management, business development and entrepreneurial leadership in MSMEs}

From a functional point of view, small businesses generally feel the effects of market pressures. May be their small size, resource limitations and newness to the market (Garnsey, 1998; Penrose, 1959; Stinchcombe, 1965) exposes them more that their established counterparts. Indeed, managing and developing MSMEs in ephemeral markets is a challenge in comparison with established firms because they have to deal with limited financial and human capital in their response to the environmental constraints (Duncan, 1972; Robinson, 1982). Therefore, it is to be expected that in such markets effective business management and leadership skills would be vital for their sustainable growth and development.

For MSMEs described as active in multiple business sectors the statement above can be true. Scholars (e.g. Daft et al., 1988; Day and Schoemaker, 2005) have acknowledged that actively scanning general economic and business conditions, technological trends and capabilities as well as constantly striving for a competitive position in saturated markets is a management function responsible for turning most underperforming businesses around. 
Simba and Thai (2018)

Journal of Small Business Management

Despite this evidence in the literature, though limited, pointing to the importance of management and development capabilities, Stefanovska and Soluncevski (2015) explained that MSMEs still lack these essential skills.

As previously discussed MSMEs have a rather linear structure running through their owners with a small number of employees (Bonger and Chileshe, 2013; Reeg, 2013a, 2015; USAID, 2007) who simultaneously perform multiple job functions. Based on this seemingly demanding working drill, issues to do with management and business development are highly likely to emerge. Therefore, the probability that a large percentage of these businesses devote less time and attention to environmental analysis is high, and yet doing so should form the basis for effective business management methods and development strategies (Stefanovska and Soluncevski, 2015).

Elsewhere, Mangham and Silver (1986); Curran et al. (1996) shared similar views that ownermanagers in small businesses do not invest enough time in training and management practices which seriously hinders the growth and development of their companies. The tendency in these small firms is to link management practices with individual capabilities to the characteristics of the owner-manager (Ates et al., 2013). What is also common in these small firms, especially MSMEs, is that their owner-managers juggle several roles while at the same time taking responsibility of key business functions including operations and strategic formulation (Reeg, 2013a). Their management style emerges mostly as a response to internal operational needs that often surface at the start-up stage (Ates et al., 2013). Business process improvements are not often the result of strategic planning, but rather are made only in response to contingent and emerging problems and often provide short-term solutions (Jennings and Beaver, 1997). 
Simba and Thai (2018)

Journal of Small Business Management

According to Ates et al. (2013) any attention to technical aspects of the business and developmentrelated problems often arise from the conviction that the only real determining factor for competitive success is the technical excellence of the product and production processes. With respect to MSMEs, managerial tools and techniques are perceived as being of little benefit to the company. The absence of management processes (Kuratko, 2017) suggests that there is no processual organisation in MSMEs. Any form of planning is carried out on an ad-hoc basis. The consequences of such behaviours are that, MSMEs may not reach their full growth potential hence the necessity for entrepreneurial leadership (Leith and Volery's, 2017; Kuratko, 2007).

Both, leadership and entrepreneurship play an important role in any organisation particularly in MSMEs that spread their activities across different markets. One of their key functions pertains to environmental scanning (Timmons, 1978). Its outcomes feed into internal management processes and trigger business development and growth initiatives (Gibb and Davies, 1990; Greiner, 1972). Indeed, constantly monitoring the external market conditions is an integral part of business development (Scott and Bruce, 1987). This article does not underestimate the capabilities gap in MSMEs that often limit their ability to effectively monitor market changes (Greiner, 1998; Smallbone et al., 1995) so as to map their management and development strategies. The literature (e.g. Ates et al., 2013; Ahmad, 2012; Blackburn et al., 2013; Gherhes et al., 2016; Mazzarol et al., 2009) recognised the lack of business experience of their owner-managers in the field of business, limited technical abilities, inadequate managerial capabilities, lack of processual planning at business level, and in some cases lack of confidence and entrepreneurial training as contributing factors. Furthermore, Mwaanga (2014) commented that operational skills (including accounting and finance, business planning, quality control, health and safety regulations, marketing and human resource management) are often the sources of management and development complications in MSMEs. This implies that managerial characteristics and developmental processes affect the growth of most enterprises (Watson et al., 2011). 
Simba and Thai (2018)

Journal of Small Business Management

So, in order to obtain the functional competencies and self-competencies (Bagheri et al., 2012) mentioned earlier, entrepreneurial leadership may provide new light for MSMEs through its multidimensional approach to management and business development. This view is advanced in this article and it is also reflected upon by Bonger and Chileshe who commented that "much of current drive for MSME development is being championed from an entrepreneurship development perspective" (2013, p.13). Moreover, it is also embedded in one of the earlier conceptualisations of entrepreneurial leadership provided in Cunningham and Lischeron (1991) who clarified that entrepreneurial leadership involves setting clear goals, creating opportunities, empowering people, preserving organisational intimacy, and developing a human resource system.

\section{Methodological justification}

This inductive research study was designed to build theory (Glaser, 2002) in order to advance entrepreneurial leadership as a practice in MSME management and development. On the basis of scattered previous conceptual knowledge concerning management and development activities specifically in MSMEs, the research adopted an exploratory approach (Guba and Lincoln, 1994). Exploratory studies are associated with inductive designs (Saunders et al., 2007) and they enable theory formation (Strauss and Corbin, 1998). Accordingly, the research was able to delve into the literature on entrepreneurial leadership to gain in-depth insights and new perspectives for describing the complex management and development activities of MSMEs, consequently, mapping a new path for MSMEs using the multi-dimensional constructs of entrepreneurial leadership. 
Simba and Thai (2018)

Journal of Small Business Management

Since the study is literature-based, a key question in achieving its stated goals, stated above, related to an appropriate literature review technique to adopt. This research design-related question resulted in a trade-off favouring a traditional/narrative literature technique as opposed to a systematic (Boland et al., 2017; Gouch et al., 2012). Adopting a systematic review approach would have restricted the analysis of secondary data to studies with a specific research design(s) e.g. metaanalysis (featuring quantitative findings) or meta-synthesis (with findings mainly from multiple qualitative research studies (Cronin et al., 2008). Systematic reviews tend to follow rigid criteria which requires spelling out the inclusion and exclusion criterion (Coughlan et al., 2007).

On that basis, a traditional or narrative literature review (Cronin et al., 2008) was deemed appropriate in that the research was able to sift through a sizeable and related body of literature (Branley et al., in Seale 2018) on entrepreneurial leadership, management and business development in small businesses. The headings in the literature review section were organised into relevant entrepreneurial leadership themes following Saunders et al. (2007) "relevance tree" technique.

Although traditional literature reviews originate from clinical related studies (Aveyard, 2010; Beecroft et al., 2006), utilising their basic technique, in this article, enabled the research to benefit from the literature entrepreneurship, leadership and entrepreneurial leadership leading to development of nuanced insights and an instructive model prescribing managerial and development activities for MSMEs. Moreover, adopting the principles of a traditional literature review (Bryman, 2008; Cronin et al., 2008; Gouch et al., 2012; Gray, 2018) deepened and widened the research enabling the study to assimilate and synthesise (Boland et al., 2017) the constructs of entrepreneurial leadership including management and business development in MSMEs. 
Simba and Thai (2018)

Journal of Small Business Management

\section{Discussions}

Most MSMEs that are currently active in developing, emerging economies and to some extent advanced economies do not seem to follow a developmental business path that starts in a modest way and eventually develops much more complicated and sophisticated processes of production (Reeg, 2013a). Reeg (2015) explained that MSMEs often lack the know-how for improving and developing their businesses further. This lack of a structured development path and know-how in MSMEs points them towards entrepreneurial leadership as a possible solution for plotting effective management and business development strategies, hence it was focused on in this article. According to Smallbone et al. (1995) active strategies are a necessity in small businesses in terms of achieving business development and growth.

A common problem that is often recycled in the scholarly works on small business management concerns their owner-managers (Chaston, 2010; Down, 2013). They are known to juggle several roles in their businesses (Ahmad, 2012; Shrader et. al., 1989; Smallbone et al., 1995). As they do so, they show obvious signs of lacking the necessary time and heterogeneous skills resulting in the negligence of managerial and business development issues (Fuller-Love, 2006). Because of their neglected managerial and developmental issues, it becomes extremely challenging for them to grow their businesses to a point where they are able to manage day-to-day operations effectively (Gray, 2002). This inevitably contributes to the failure of their ventures (Longenecker et al., 2014). To reduce such failures Fuller-Love (2006) expressed that management development is necessary for improving the skills of managers and for ultimately developing organisational capabilities. In their contribution to this debate, Hill and Stewart (2000) explained the management and business development methods common in MSMEs. Hill and Stewart clarified that their management methods are often "informal, reactive and short-term in outlook" (2000, p.114). Related to this, Kotey and Slade (2005) explained that there is a high degree of informality in micro-sized small businesses. 
Simba and Thai (2018)

Journal of Small Business Management

In comparison with large organisations, MSMEs or small-sized enterprises follow a more personalised management approach which is less-formal (Wilkinson, 1999). Clearly, there is consensus in the literature that business management in small businesses is largely carried out through informal means (see for example: Blackburn et al., 2013; Gibb and Scott, 1985; Robinson and Pearce, 1984; Shrader et. al., 1989). Such informality may be due to a combination of the manager-employee proximity in smaller businesses and, again, lack of resources (Bardoel et al., 1999; Kinnie et al., 1999).

Informality may have its roots in entrepreneurship, but it is equally important to recognise that organisational planning and/or formal systems are necessary in MSMEs as ways of harnessing entrepreneurial outcomes (Chaston, 2010; Duane et al., 2009) in the various business sectors they trade. As such, the focus on entrepreneurial leadership, in this article, initiates progression towards instituting effective management and business development methods in MSMEs.

The mutual cross fertilisation (Leitch and Volery, 2017) between entrepreneurship and leadership positions entrepreneurial leadership as a grounded theoretical proposition that can benefit small business management and development initiatives in meaningful and applicable ways. Clearly, in its absence, MSMEs that operate in multiple markets would, most likely, find it hard to develop and grow. Perhaps this validates the rationale for proposing the multi-dimensional entrepreneurial leadership paradigm as an instructive framework in the management and development of MSMEs (Roxie et al., 2008) especially in the multiple markets they operate in (Bagheri et al., 2012). 
Simba and Thai (2018)

Journal of Small Business Management

\section{Mapping a new path for MSME}

The emergence of entrepreneurial leadership as a paradigm to use for recommending fresh management and development methods for businesses is timely and promising particularly for MSMEs, in several ways. Firstly, it provides vital instructive tools that would assist MSMEs to plot their way through the rough business terrain, often triggered by market instability (Duane et al., 2009; Longenecker et al., 2014). Secondly, it evokes new strategic thinking (Hitt et al., 2001; Ireland et al., 2003; Ireland et al., 2009) for their owner-managers/leaders in ways they may have never been able to before. Thirdly, entrepreneurial leadership provides new theoretical and applied methods for addressing management and business development-related complications as well as ideas for avoiding strategic dissonance (Burns, 2014; Timmons and Spinelli, 2009) in MSMEs. Its theoretical and practical influence hypothesised above, marks its advent as a potent paradigm for understanding management and business development in entrepreneurial ventures.

\section{The theoretical implications of the new framework}

In order to plot a new path for MSME management and development, Figure 1 is presented as an instructive and multivariate framework. It inculcates owner-managers in MSMEs to concentrate on developing their functional and self-competencies using the entrepreneurial leadership microscope. As part of their development exercise, the multivariate entrepreneurial leadership framework can be utilised as the base that supports management and business development practices in MSMEs. Considering that dealing with environmental uncertainty is a major problem for entrepreneurs (Floren, 2006; Gupta et al., 2004; Wynarczyk et al., 1993) in general; entrepreneurial thinking, opportunity-seeking, risk bearing, and proactive behaviour should define their business approach (Nicholson, 1998). 
Simba and Thai (2018)

Journal of Small Business Management

Applying such behavioural traits in business modelling demonstrates the impact of the entrepreneurship and leadership cross-fertilisation manifested in entrepreneurship and leadership density (Kuratko, 2018; Matthews, 2017) within the new Framework. Without focussing on entrepreneurial systems in MSMEs, the process of crafting an effective business plan fitting their multiple markets would be a mammoth task for their owner-managers or leaders. As such, drawing on the fusion of entrepreneurship and leadership to inform the business planning process sets the path for their success within their entrepreneurial context. Accordingly, the new Framework shows management knowledge and business development techniques embedded in entrepreneurship and leadership density as directly influencing planning. Furthermore, utilising this density as a template for organising and planning business activities in MSMEs may also defuse operations-related constrains that often characterise turbulent markets.

Figure 1: Advancing entrepreneurial leadership as a practice for the management and development activities of MSMEs

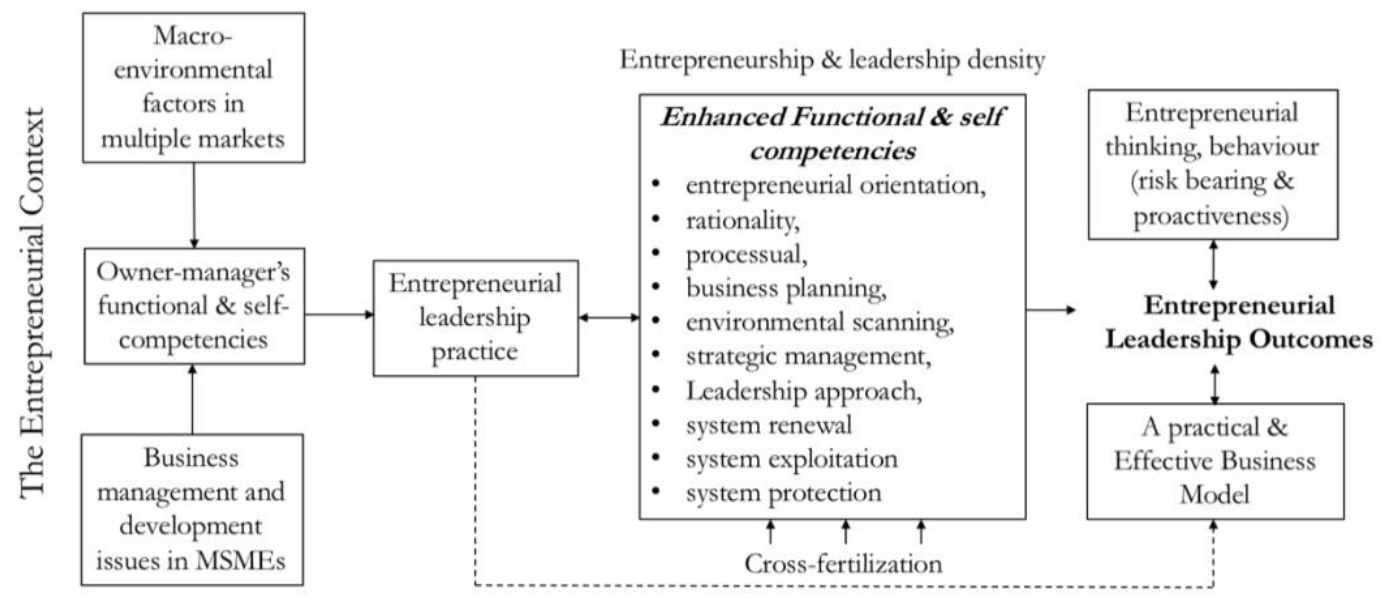

Moreover, the new framework suggests that owner-managers must calibrate informality and structure in their MSMEs through engaging in systematic business planning and organisation. This integrated and holistic way of doing business will undoubtedly enhance their chances of being effective leaders and for enabling the success of their business. 
Simba and Thai (2018)

Journal of Small Business Management

Another important assumption the Framework advances concerns the development of the ownermanagers own abilities. It illustrates that developing a mixture of competencies would improve their awareness of the need for additional leadership capacity within themselves and others in the firm (Carsrud et al., 2018). Doing so is envisaged to contribute towards achieving the management and development goals of their ventures. From that perspective, the framework may inspire them to be indifferent to social distractions (Nicholson, 1998), and to be energised by the thought of success in their multiple markets. Thus, it invites them to envision and enact a proactive transformation of their MSMEs' transaction set.

\section{The practical Implications of the new framework}

The theoretical and practical appeal the new Framework recommends, has implications for how owner-managers/leaders manage and develop their businesses in distinct markets. Clearly, its emphasis on cross-fertilisation makes it applicable in different contexts. On that basis, there is ground for extending its utility in several types of contemporary firms that operate in today's globalised markets. For example, it can be utilised in entrepreneurial firms including; international new ventures (INVs), family businesses, multinational enterprise to defuse management and business development issues. Indeed, as the world markets continue to converge, uncertainty is unavoidable (Simba and Ndlovu, 2015). Therefore, organisations of all sizes have no choice, but to prioritise the search for theoretical and practical solutions for their business management and development problems. Against that backdrop, this article has demonstrated that entrepreneurial leadership offers new applied knowledge with the capacity to unlock management and development complications in most firms. Thus, the proposed model in Figure 1 is timely. 
Simba and Thai (2018)

Journal of Small Business Management

Arguably, the way in which entrepreneurial leadership has been articulated in Figure 1, clearly signals the advent of an integrated and holistic approach for instructing management and business development activities in contemporary firms. At the core of such activities is entrepreneurial leadership and managers/CEOs/owners of various types of businesses have to appreciate its benefits. Particularly, the individual and organisational benefits associated with entrepreneurship and leadership. For academics, the various angles of debate concerning the theoretical intersection between entrepreneurship and leadership this article presents, offer them new knowledge that has for long been absent.

\section{Conclusions}

This article validated entrepreneurial leadership as a practice in MSMEs, in particular, and small businesses, in general. It has engaged in the debate about management and business development methods in these small-sized firms and has mapped a new way that may be applied to small businesses in general.

Given that the majority of MSMEs' management and businesses development activities hinge on the capabilities of their owner-managers, the research highlighted the need for these individuals to pay attention to the development of their functional and self-competences to grow their businesses. Clearly, in the multiple business sectors MSMEs trade (Bonger and Chileshe, 2013) both endogenous and exogenous factors (Timmons, 1978) conspire to influence their business activities, and under such conditions an integrated business framework anchored on entrepreneurial leadership was offered, in this article, as a possible way for providing theoretical and applied management and business development solutions. 
Simba and Thai (2018)

Journal of Small Business Management

The way in which entrepreneurial leadership has been utilised to plot a path for management and business development in MSMEs forms a key part of contributions that the subject matter of this study is essentially about. Indeed, given that MSMEs operate in multiple business sectors and are profoundly influenced by their owner-managers, the cross fertilisation between entrepreneurship and leadership advanced in this research, has offered refined theoretical and functional ways for mapping their management and business development methods. Considering that existing management and development paradigms originate from studies that have focused only on large and established businesses their use for the purposes of studying MSMEs would be problematic. Therefore, advancing entrepreneurial leadership practice when simultaneously debating management and business development activities in MSMEs was timely. Particularly, in providing vital instructive tools that would assist MSMEs to map their way through a rough business terrain often triggered by market instability (Duane et al., 2009; Longenecker et al., 2014). Moreover, it modifies thinking within MSMEs in ways they may have never been able to before.

\section{Research limitations}

As much as the chosen research method was deemed appropriate it has its inherent limits. For example; the traditional or narrative literature review approach adopted for this study provided a critical appraisal and analysis of the wider literature on entrepreneurial leadership, whereas a systematic literature review approach would have required the study to explicitly adhere to a rigid protocol for screening secondary sources based on research design. Nonetheless, the rationale for adopting a traditional or narrative literature review approach was to cover the wider literature on entrepreneurship and leadership in order highlighting and advance the benefits of a crossfertilisation in managing and developing small businesses. 
Simba and Thai (2018)

Journal of Small Business Management

\section{Suggestion for future studies}

As the voices calling for more attention on entrepreneurial leadership continue to grow louder (see Kuratko, 2007; Leitch and Volery, 2017; Harrison and Leitch, 2018; Hutchinson, 2018), this study responds by offering theoretical perspectives that introduce new ways for applying the concept in MSMEs. In doing so, the article sets the tone for future studies. To continue advancing this new concept, scholars and practitioners in both the entrepreneurship and leadership disciplines are invited to test the applicability of the theoretical perspectives this article has offered in different entrepreneurial contexts. As Kuratko $(2007,8)$ puts it "the more we can understand the elements that comprise this concept, the more we can advance the concept itself'. This will have significant implications in terms of how entrepreneurial firms, whether large or small, may be managed in the future.

\section{Reference:}

Abdelgawad SG, Zahra SA, Svejenova S, et al. (2013). "Strategic leadership and entrepreneurial capability for game change," Journal of Leadership and Organizational Studies 20(4) 394-407.

Acs Z. J. and Storey D. J. (2004). "Introduction: entrepreneurship and economic development", Regional Studies 38(8), pp.871-877.

Ahmad, A, and Nwankwo, S., (2013). "Entrepreneurship development in Africa: an overview," World Journal of Entrepreneurship, Management and Sustainable Development 9(2/3), pp. 82-86.

Ahmad, A., (2012). Micro, small and medium-sized enterprises development in the Kingdom of Saudi Arabia: Problems and constraints", World Journal of Entrepreneurship, Management and Sustainable Development 8(4), pp. 217-232

Alvarez, C., Urbano, D., Coduras, A. and Ruiz-Navarro, J., (2011). "Environmental conditions and entrepreneurial activity: a regional comparison in Spain", Journal of Small Business and Enterprise Development 18(1), pp.120-140.

Antoncic, B. (2003). "Risk taking in intrapreneurship: Translating the individual level risk aversion into the organizational risk taking," Journal of Enterprising Culture, 11(1), pp.1-23.

Ates, A., Garengo, P., Cocca, P., and Bititci, U., (2013). "The development of SME managerial practice for effective performance management", Journal of Small Business and Enterprise Development 20(1), pp. 28-54.

Audretsch, D.B. and Keilbach, M., (2004). "Entrepreneurship and regional growth: an evolutionary interpretation," Journal of Evolutionary Economics, 14(5), pp.605-616.

Aveyard, H., (2010), Doing a literature review in health and social care: A practical guide, 2nd ed. Berkshire, England: Open University Press.

Bagheri, A., Pihie, Z. A., \& Krauss, S. E., (2012), "Entrepreneurial leadership competencies among Malaysian university student entrepreneurial leaders," Asia Pacific Journal of Education 33(4), pp. 493-508. Available at: http://dx.doi.org/10.1080/02188791.2013.822789, Accessed on 25/11/2017. 
Simba and Thai (2018)

Journal of Small Business Management

Bardoel, A. E., Moss, S. A., Smyrnios, K., and Tharenou, P. (1999), "Employee characteristics associated with the provision of work-family policies and programs", International Journal of Manpower, 20(8), pp. 563-577.

Bass, B. M. (1985). Leadership and performance beyond expectations. New York: Free Press

Bass, B.M. and Stogdill, R.M., (1990). Bass \& Stogdill's handbook of leadership: Theory, research, and managerial applications. Simon and Schuster.

Beaver, G., (2002). Small Business, Development, Pearson Education Limited, Harlow: England, ISNB: 13-178-0273-65105-5.

Beecroft C, Rees A, and Booth, A., (2006), Finding the evidence. In: Gerrish K, Lacey A, eds. The Research Process in Nursing. $5^{\text {th }}$ Ed. Blackwell Publishing, Philadelphia: pp. 90-106

Bell, R. G and Whittington, J. L., 2018; Enabling the full range of leadership across the organisational life cycle and growth states of entrepreneurial firms. Harrison, R, T., and Leitch, C, M (2018), Research Handbook on Entrepreneurial Leadership, Edward Elgar Publishing, Massachusetts, USA. DOI: 10.43379781783473762.

Berry, A., von Blottnitz, M., Cassim, R., Kesper, A., Rajaratnam, B. and van Seventer, D. E. (2002), "The economics of SMMES in South Africa", Trade and Industrial Policy Strategies (TIPS) Report, Johannesburg. Available at: http://www.tips.org.za/files/506.pdf, Accessed on 15.11.2017

Blackburn, R. A, Hart, M. and Wainwright, T., (2013), "Small business performance: business, strategy and owner-manager characteristics," Journal of Small Business and Enterprise Development 20(1), pp. 8-27

Block, Z. and MacMillan, I. C., (1993), Corporate venturing: Creating new businesses within the firm," Boston: Harvard Business School Press.

Boland, A, Cherry, M. G., and Dickson, R., (2017), Doing a systematic literature review: A student's guide, $2^{\text {nd }}$ Edition, SAGE Publications, Thousand Oaks: California, ISBN: 978-1-473967007.

Bolton Report (The) (1971), Small Firms, Report of the Committee of Inquiry on Small Firms, HMSO, Cmnd. 4811, London.

Bonger, T. and Chileshe, C., (2013), "The State of Business Practices and the Impact of BDS on MSMEs in Lusaka and Kabwe, Zambia”, ICBE-RF Research Report NO. 76/13 Investment Climate and Business Environment Research Fund (ICBE-RF), Available at: www.trustafrica.org/icbe, Accessed on 11/11/2017.

Burns, B., (2014), Managing Change, $6^{\text {th }}$ Edition, Pearson Education Limited, Hallow: UK. ISBN: 978-0-273-77896-7.

Branley, D. Seale, C. and Zacharias, T., (2018), Doing a literature review In Seale, C. (2018), Researching Society and Culture, $4^{\text {th }}$ Edition, Thousand Oaks: California, ISBN: 198-1-47394715-3.

Breslin, D. (2011). Evolution and Entrepreneurship. In Mole, K and Ram, M. (Eds), Perspectives in Entrepreneurship: A Course Text, Palgrave, London, pp. 107-119.

Bridge, S. and O'Neill, K., (2018). Understanding Enterprise: Entrepreneurship and Small Business, $5^{\text {th }}$ Edition, Palgrave Macmillan, London, ISBN: 978-1-137-58454-0

Bridge, S., (2017). The search for entrepreneurship: Finding more Questions than Answers, London: Routledge, p60.

Bryman, A., (2008), Social research methods, $3^{\text {rd }}$ Edition, Oxford University Press, USA.

Burns, P., (2016), Entrepreneurship and Small Business: Start-up, Growth and Maturity, Palgrave Macmillan. London, ISBN: 978-1-137-43035-9.

Burns, P., (2014), New Venture Creation: A Framework. for Entrepreneurial Start-ups, Palgrave Macmillan, Basingstoke: Hampshire. ISBN: 978-1-13733289-9.

Burns, P., (2012), Corporate entrepreneurship: innovation and strategy in large organizations. Palgrave Macmillan. 
Simba and Thai (2018)

Journal of Small Business Management

Burns, P., (2010), Entrepreneurship and Small Business: Start-up. Growth and Maturity. Palgrave Macmillan. London.

Cardon, M.S., Zietsma, C., Saparito, P., Matherne, B.P. and Davis, C., (2005), "A tale of passion: New insights into entrepreneurship from a parenthood metaphor", Journal of Business Venturing, 20(1), pp.23-45.

Carsrud, A. L., Renko-Dolan, M. and Brännback, M., (2018), Understanding entrepreneurial leadership: Who leads a venture matters. In Harrison, R, T., and Leitch, C, M (2018), Research Handbook on Entrepreneurial Leadership, Edward Elgar Publishing, Massachusetts, USA. DOI: 10.43379781783473762.

Chaston, I., (2010), Entrepreneurial Management in Small Firms, SAGE Publications, Thousand Oaks, California, ISBN 978-1-84860-024-9

Coglister, C and Brigham, K., (2004), "The intersection of leadership and entrepreneurship: Mutual lessons learned," The Leadership Quarterly 15(6) pp. 771-799.

Coughlan M, Cronin P, and Ryan, F., (2007), "Step-by-step guide to critiquing research. Part 1: quantitative research," British Journal of Nursing 16(11), pp.658-63.

Covin, J. G., and Slevin, D. (2002), "The Entrepreneurial Imperatives of Strategic Leadership," in Strategic Entrepreneurship: Creating a New Mind-set. Eds. M. A. Hitt, R. D. Ireland, S. M. Camp and D. L. Sexton. Oxford: Blackwell Publishers, 309-327.

Covin, J. G. and Slevin, D. P., (1991), "A conceptual model of entrepreneurship as firm behavior," Entrepreneurship Theory and Practice, 16(1), 7-25.

Cronin, P., Ryan, F. and Coughlan, M., (2008), "Undertaking a literature review: a step-by-step approach," British Journal of Nursing 17(1), pp.38-43.

Cunningham, J. B., and J. Lischeron (1991), "Defining Entrepreneurship," Journal of Small Business Management 29(1), 45-62.

Curran, J., Blackburn, J.K., Kitchins, J. and North, J. (1996), “Establishing Small Firms' Training Practices, Needs, Difficulties and Use of Industry Training Organisations", Department of Education and Employment/HMSO, London.

Daft, R.L., Sormunen, J. and Parks, D. (1988), "Chief executive scanning environmental characteristics and company performance: an empirical study", Strategic Management Journal 9(2), pp. 123-39.

Darling, J. R., Keeffe, M. J. and Ross, J, K., (2007), "Entrepreneurial Leadership Strategies and Values: Keys to Operational Excellence", Journal of Small Business \& Entrepreneurship, 20(1), pp. 41-54, DOI: 10.1080/08276331.2007.10593385

Day, G.S. and Schoemaker, P. J. H., (2005), "Scanning the periphery", Harvard Business Review 83(11), pp. 135-48.

Dess, G. G., Ireland, R. D., Zahra, S. A., Floyd, S. W., Janney, J. J., and Lane, P. J., (2003), "Emerging issues in corporate entrepreneurship", Journal of Management 29(3), 351-378.

De Wit, B., \& Meyer, R. (2014), Strategy: An international perspective. Cengage Learning.

Down, S., (2013), Enterprise, Entrepreneurship and Small Business, SAGE Publications, Thousand Oaks, California, ISBN 978-1-4129-0884-9.

Duane, I, Jeffery G. Covin, and Kuratko, D. F., (2009), “Conceptualizing Corporate Entrepreneurship Strategy", Entrepreneurship Theory and Practice 33(1), p. 24.

Duncan, R. B., (1972), "Characteristics of organisational environment and perceived environmental uncertainty", Administrative Science Quarterly 17(1972), pp.313-327

Edoho, F. M., (2015), "Entrepreneurship and socioeconomic development: Catalyzing African transformation in the 21st century", African Journal of Economic and Management Studies 6(2), pp.127-147, Available at: https://doi.org/10.1108/AJEMS-03-2013-0030, Accessed 28.10.2017.

Edoho, F.M. (1996), "Toward sustainable development in the twenty-first century: reengineering development in Sub-Saharan Africa", in James, V.U. (Ed.), Sustainable Development in Third 
Simba and Thai (2018)

Journal of Small Business Management

World Countries: Applied and Theoretical Perspectives, Praeger Publishers, Westport, CT, pp. 154-166.

El-Namaki, M. S. S., (1992), “Creating a Corporate Vision”, Long Range Planning 25(6), pp. 25-29 Engelen, A., Gupta, V., Strenger, L., and Brettel, M. (2012), "Entrepreneurial Orientation, Firm Performance, and the Moderating Role of Transformational Leadership Behaviours", Journal of Management. DOI: 10.1177/0149206312455244.

Fernald, L W, Jr; Solomon, G. T, and Tarabishy, A., (2005), “A New Paradigm: Entrepreneurial Leadership”, Southern Business Review Spring (2005) 30(2), pp. 1-10.

Floren, H. (2006), "Managerial work in small firms: summarising what we know and sketching a research agenda", International Journal of Entrepreneurial Behaviour and Research 12(5), pp. 272 88.

Fontana, A, and Musa, S., (2017), "The impact of entrepreneurial leadership on innovation management and its measurement validation", International Journal of Innovation Science, 9(1), pp.2-19, Available at: https://doi.org/10.1108/IJIS-05-2016-0004, Accessed on $24 / 11 / 2017$

Franco, M and Matos, P. G., (2015), "Leadership styles in SMEs: a mixed-method approach", International Entrepreneurship and Management Journal 11(2), pp.425-451.

Freiling, J. (2007), "SME Management - What Can We Learn from Entrepreneurship Theory?” Available at SSRN: https://ssrn.com/abstract $=984658$ or http://dx.doi.org/10.2139/ssm.984658, Accessed on 15.11.2017

Fuller-Love, N., (2006), "Management development in small firms", International Journal of Management Reviews 8(3), pp. 175-190. DOI: 10.1111/j.1468-2370.2006.00125.x.

Gartner, W, B, Carter N. M and Reynolds, P. D., (2010), Entrepreneurial behavior: Firm organizing processes. In: Acs Z and Audretsch D (Eds) International Handbook Series on Entrepreneurship, vol. 5. New York: Springer, pp. 99-127.

Gartner, W. B., Bird, B. J. and Starr, J. A., (1992), “Acting as If: Differentiating Entrepreneurial from Organizational Behavior", Entrepreneurship Theory and Practice 16(3), 1331.

Garnsey, E., (1998), "A theory of the early growth of the firm”, Industrial and corporate change 7(3), 523-556.

Gherhes, C., Williams, N., Vorley, T., and Vasconcelos, A. C. (2016), "Distinguishing microbusinesses from SMEs: a systematic review of growth constraints", Journal of Small Business and Enterprise Development 23(4), pp. 939-963.

Gibb, A. A., (2000), "SMEs Policy, Academy Research and Growth of Ignorance", International Small Business Journal, 18(3), pp13

Gibb, A. A., and Scott, M., (1985), "Strategic Awareness, Personal Commitment and the Process of Palling in the Small Business", Journal of Management Studies 22(6), pp.597-631.

Gibb, A., \& Davies, L. (1990), "In pursuit of frameworks for the development of growth models of the small business", International Small Business Journal 9(1), pp.15-31.

Glaser, B, G., (2002), "Conceptualization: On theory and theorizing using grounded theory". International Journal of Qualitative Methods 1(2), pp. 23-38.

Gough, D., Oliver, S., and Thomas, J., (2012), An introduction to systematic literature reviews, SAGE Publications Ltd, Thousand Oaks: CA.

Goossen, R. J., and Stevens, R. P., (2013), Entrepreneurial Leadership: Finding Your Calling, Making a Difference. Downers Grove, IL: Intervarsity Press.

Guba, E. G., and Lincoln, Y. S. (1994), Competing paradigms in qualitative research. Handbook of qualitative research, 2(163-194), 105.

Gupta, V. M., I. C. MacMillan, and Surie, G. (2004), "Entrepreneurial leadership: Developing and measuring a cross-cultural construct", Journal of Business Venturing, 19(2), pp.241-260.

Gray, D. E., (2018), Doing Research in the Real World, $4^{\text {th }}$ Edition, SAGE Publications, Thousand Oaks: California. ISBN: 978-1-4739-4726-9. 
Simba and Thai (2018)

Journal of Small Business Management

Gray, C. (2002), "Entrepreneurship, resistance to change and growth in small firms", Journal of Small Business and Enterprise Development, 9(1), 61-72.

Greiner, L. E., (1972), "Evolution and revolution as organizational growth", Harvard business review, 4, pp.98-114.

Greiner, L. E., (1998), "Evolution and revolution as organizations grow", Harvard business review, 76, pp. 55-69.

Hansson, F. and Mønsted, M. (2008), "Research leadership as entrepreneurial organizing for research", Higher Education 55(6), pp. 651-70.

Harrison, C., Paul, S., and Burnard, K. (2016), "Entrepreneurial Leadership: A Systematic Literature Review", International Review of Entrepreneurship 14(2), 235-264.

Harrison R. T, Leitch, C. M and McAdam, M., (2015), "Breaking glass: Towards a gendered analysis of entrepreneurial leadership", Journal of Small Business Management 53(3), pp. 693713.

Harrison, R. T, and Leitch, C., (1994), "Entrepreneurial and leadership: The implication for education and development", Entrepreneurship and Regional Development 6, pp.125.

Hatem, O. M., (2018) Entrepreneurial Distributed Entrepreneurship in the emergence and development of high growth internationalising firms. In Harrison, R, T., and Leitch, C, M (2018), Research Handbook on Entrepreneurial Leadership, Edward Elgar Publishing, Massachusetts, USA. DOI: 10.43379781783473762.

Hill, R. and Stewart, J. (2000), "Human resource development in small organisations", Journal of European Industrial Training, 24(2/3/4), pp. 105-117.

Hitt, M. A., Ireland, R. D., Camp, S. M., and Sexton, D. L. (2001), "Strategic entrepreneurship: Entrepreneurial strategies for wealth creation", Strategic Management Journal 22(6-7), pp. 479-491.

Hitt, M. A., and Ireland, R. D. (2005), "Strategic entrepreneurship", In M. A. Hitt \& R. D. Ireland, (Eds.), The Blackwell encyclopaedia of management: Entrepreneurship (pp. 228-231). Oxford, UK: Blackwell Publishers.

International Council for Small Business (ICSB), (2015), Entrepreneurial Leadership at a Crossroads, ICSB World Conference Proceedings; Washington - pp.1-13. WashingtonInternational Council for Small Business (ICSB). (2015)

Ireland, R. D., Hitt, M. A. and Sirmon, D. G., (2003), "A Model of Strategic Entrepreneurship: The Construct and Its Dimensions", Journal of Management Development 29(6), pp. 963-989.

Ireland, R. D., Covin, J. G., and Kuratko, D. F., (2009). "Conceptualizing corporate entrepreneurship strategy", Entrepreneurship theory and practice 33(1), 19-46.

Ireland, R.D., Covin, J.G. and Kuratko, D.F., (2009), "Conceptualizing corporate entrepreneurship strategy", Entrepreneurship Theory and Practice 33(1), pp.19-46.

Jennings, P. and Beaver, G., (1997), "The performance and competitive advantage of small firms: a management perspective", International Small Business Journal 15(2), pp. 34-58.

Jones, O., and Crompton, H., (2009), "Enterprise logic and small firms: a model of authentic entrepreneurial leadership", Journal of Strategy and Management 2(4), pp. 329-351, DOI 10.1108/17554250911003836.

Johnson, G. Whittington, R. Scholes, K. Angwin D. and Regner, P., (2014), Exploring Strategy: Text and Cases, $10^{\text {th }}$ Edition, Pearson Education Limited, Hallow: UK

Kansikas, J, Laakkonen, A, Sarpo, V, and Kontinen, T., (2012), "Entrepreneurial leadership and familiness as resources for strategic entrepreneurship", International Journal of Entrepreneurial Behaviour \& Research 18(2), pp. 141-158, DOI 10.1108/13552551211204193.

Kinnie, N., Purcell, J., Hutchinson, S., Terry, M., Collinson, M. and Scarbrough, H. (1999), "Employment relations in SMEs: market-driven or customer-shaped?", Employee Relations, 21(3), pp. 218-35 
Simba and Thai (2018)

Journal of Small Business Management

Kibera, L. W., (2000), The role of small Scale enterprises in socio-economic development and poverty alleviation in Kenya: a gender perspective. 7th Annual International Management Conference (pp. 38-48). Kampala: Makerere Business Journal Publications School.

Kotey, B., and Slade, P. (2005), "Formal human resource management practices in small growing firms", Journal of small business management, 43(1), 16-40.

Kraus, S, Reiche, B. S. and Reschke, C. H., (2007), "Implications of strategic planning for SMEs for international entrepreneurship research and practice", Published in M. Terziovski (Ed.), Energizing Management through Innovation and Entrepreneurship: European Research and Practice, pp. 110-127. London: Routledge.

Klins, U., (2014), "Small Business Development and the Inclusive Business Concept", ICBE-RF Research Report N0. 82/14, Investment Climate and Business Environment Research Fund, Available at: http://www.trustafrica.org/en/publications-trust/icbe-researchreports, Accessed on 29.10.2017.

Koryak O, Mole KF, Lockett A, et al. (2015), Entrepreneurial leadership, capabilities and firm growth", International Small Business Journal 33(1), pp. 89-105.

Kuratko, D.F., (2017), Entrepreneurship: Theory, Process, and Practice. Cengage Learning, Boston: USA

Kuratko, D. F., (2018), The Challenge of Corporate Entrepreneurial Leadership. In Harrison, R, T., and Leitch, C, M (2018), Research Handbook on Entrepreneurial Leadership, Edward Elgar Publishing, Massachusetts, USA. DOI: 10.43379781783473762 .

Kuratko, D. F., (2007), "Entrepreneurial leadership in the 21st century”, Journal of Leadership and Organisational Studies 13(4): 1-11.

Kuratko, D. F, Hornsby, J. S. and Goldsby, M. G., (2004), "Sustaining Corporate Entrepreneurship: Modeling Perceived Implementation and Outcome Comparisons at Organizational and Individual Levels", International Journal of Entrepreneurship and Innovation 5(2), pp77-89.

Kuratko, D. F., (2018) The challenges of Corporate Entrepreneurial Leadership. In Harrison, R, T., and Leitch, C, M (2018), Research Handbook on Entrepreneurial Leadership, Edward Elgar Publishing, Massachusetts, USA. DOI: 10.43379781783473762.

Kuratko, D. F. (2014), Entrepreneurship: Theory, Process, Practice, 9th edn. Mason, OH: Cengage Publishing.

Kuratko, D. F. and Audretsch, D. B. (2013), "Clarifying the domains of corporate entrepreneurship", International Entrepreneurship and Management Journal, 9 (3): 323 - 35.

Harrison, R, T., and Leitch, C, M (2018), Research Handbook on Entrepreneurial Leadership, Edward Elgar Publishing, Massachusetts, USA. DOI: 10.43379781783473762.

Hutchinson, K., (2017), Leadership and Small Business: The Power of Stories, Palgrave Macmillan US, Cham. Available from: ProQuest E-book Central. Available at:

https://ebookcentral.proquest.com/lib/ntuuk/detail.action?docID=5024020\#, Accessed 2 April 2018.

Lall, S., (2000), Strengthening SMES for International Competitiveness. Workshop on What Makes Your Firm Internationally Competitive? Cairo Egyptian Center for Economic Studies, March 6-8, 2000, Available at:

https://pdfs.semanticscholar.org/8e65/be07b909b0f44e6cccb1155ee6bf7b44c03a.pdf, Accessed on 6.12.2017Leitch, C, M and Volery, T., (2017), "Entrepreneurial leadership: Insights and directions", International Small Business Journal 35(2), pp.147-156.

Leitch, C, M, McMullan, C and Harrison, R, T, (2013), "The development of entrepreneurial leadership: The role of human, social and institutional capital", British Journal of Management 24(3), pp.347-366. 
Simba and Thai (2018)

Journal of Small Business Management

Leitch, C. M., C. McMullan, and R. T. Harrison (2009), "Leadership Development in SMEs: An Action Learning Approach," Action Learning: Research and Practice 6(3), 243-263.

Longenecker, J. G., Petty, J, W., Palich, L. E., and Hoy, F (2014), Small business management: Launching and growing entrepreneurial ventures, CENGAGE LEARNING, 17e, Stanford: USA.

Lord, R.G., Brown, D.J., Harvey, J.L. and Hall, R.J., (2001), "Contextual constraints on prototype generation and their multilevel consequences for leadership perceptions", The Leadership Quarterly, 12(3), pp.311-338.

Kibera, L. W., (2000), The role of small Scale enterprises in socio-economic development and poverty alleviation in Kenya: a gender perspective. 7th Annual International Management Conference (pp. 38-48). Kampala: Makerere Business Journal Publications School.

Mangham, I.L. and Silver, M.S., (1986), Management Training: Context and Practice, Economic and Social Science Research Council, London.

Mapunda, G., (2007), "Entrepreneurial Leadership and Indigenous Enterprise Development", Journal of Asia Entrepreneurship and Sustainability 3(3): pp. 1-16.

Mathews, J., (2017), Entrepreneurial Leadership: A Conceptual Examination. IUP Journal of Entrepreneurship Development, 14(4), pp.31-50.

Maxwell, G., Rankine, L., Bell, S., and MacVicar, A., (2007), "The incidence and impact of flexible working arrangements in smaller businesses”, Employee Relations, 29(2) pp.138 161 Permanent link to this document: http://dx.doi.org/10.1108/01425450710719987.

Mazzarol, T., Reboud, S., and Soutar, G. N., (2009), "Strategic planning in growth oriented small firms", International Journal of Entrepreneurial Behavior and Research, 15(4), pp. 320-345. http://dx.doi.org/10.1108/13552550910967912

McCarthy, A., (2014), "Leading During Uncertainty and Economic Turbulence: An Investigation of Leadership Strengths and Development Needs in the Senior Irish Public Sector", Advances in Developing Human Resources 16(1) pp. 54-73, DOI: $10.1177 / 1523422313509566$.

McClelland, D.C. (1961), The Achieving Society, Van Nostrand, Princeton, NJ.

Mitchell R, Busenitz L, Lant T, et al. (2002), "Toward a theory of entrepreneurial cognition: Rethinking the people side of entrepreneurship research", Entrepreneurship Theory and Practice 27(2) pp. 93-104.

Mwaanga, C., (2014), "Business Development Services: An Experiment of MSMEs in Central and Lusaka Provinces in Zambia", Management 4(5), pp.103-111 DOI: 10.5923/j.mm.20140405.01.

Mwangi, R. M., Sejjaaka, S., Canney, S., Maina, R et al., (2013), "Constructs of Successful and Sustainable SME Leadership in East Africa", ICBE-RF Research Report N0. 79/13, Investment Climate and Business Environment Research Fund (ICBE-RF), Available at: www.trustafrica.org, Accessed on 29.10.2017.

Naude, W. A. and Havenga, J. J. D. (2005), "An overview of African entrepreneurship and small business research”, Journal of Small Business Entrepreneurship 18(1), pp. 101-119.

Nicholson, N., (1998), "Personality and entrepreneurial leadership: A study of the heads of the UK's most successful independent companies", European Management Journal 16(5): 529_ 539.

Nielsen, S.L., Klyver, K., Evald, M.R. and Bager, T., (2017). Entrepreneurship in theory and practice: Paradoxes in Play. Edward Elgar Publishing. MA: USA. ISBN: 978-1-78536-447-1.

Ng, H.S. and Kee, D.M.H., (2018). "The core competence of successful owner-managed SMEs", Management Decision, 56(1), pp.252-272.

Northouse, P.G., 2018. Leadership: Theory and practice. Sage publications. Thousand Oaks.

Penrose, E. T. (1959), The Theory of the Growth of the Firm. Oxford University Press: New York. 
Simba and Thai (2018)

Journal of Small Business Management

Quist, A. H., (2009), “A Credible Leader for Turbulent Times: Examining the Qualities Necessary for Leading into the Future", Journal of Strategic Leadership 2(1), pp. 1-12, ISSN 1941-4668.

Osborn R. N, and Marion R., (2009), "Contextual leadership, transformational leadership and the performance of international innovation seeking alliances", The Leadership Quarterly 20 (2009) pp. 191-206. DOI: 10.1016/j.leaqua.2009.01.010.

Osborn, R.N., Hunt, J.G. and Jauch, L.R., (2002). Toward a contextual theory of leadership. The Leadership Quarterly, 13(6), pp.797-837.

Reeg, C. (2013a), Micro, small and medium enterprise upgrading in low-and middle-income countries - A literature review (Discussion Paper 15/ 2013). Bonn: German Development Institute / Deutsches Institut für Entwicklungspolitik. ISBN 978-3-88985-618-0

Reeg, C. (2015), Micro and Small Enterprises as Drivers for Job Creation and Decent Work. (Discussion Paper 10/ 2015). Bonn: German Development Institute / Deutsches Institut für Entwicklungspolitik. SBN 978-3-88985-676-0.

Renko M, Tarabishy A, Carsrud A. L, and Brännback, M., (2015), "Understanding and measuring entrepreneurial leadership style", Journal of Small Business Management 53(1) pp.54-74.

Robinson, R. B., Pearce, J. A., (1984), "Research Thrusts in Small Firm Strategic Planning", Academy of Management Review, 9(1), pp.128-137.

Robinson, R. B., (1982), "The importance of outsiders in small firm strategic planning”, Academy of Management Journal 25 (1982); 80-93.

Ropo, A. and Hunt, J.G., 1999. Leadership and organizational change: Some findings from a processual grounded theory study. Advances in qualitative organizational research, 2, pp.169200.

Roxas, H. B, Lindsay, V, Ashill, N. and Victorio, A., (2008), "Institutional analysis of strategic choice of micro, small, and medium enterprises: development of a conceptual framework", Singapore management review 30(2), pp.47-72.

Saunders, M., Lewis, P. and Thornhill, A., (2007), Research Methods for Business Students (4th Ed). Harlow: FT Prentice Hall.

Saxena, A and Jagota, R., (2015), "Should the MSMEs be Governed the Corporate Way? Indian Journal of Corporate Governance 8(1); pp.54-67. DOI: 10.1177/0974686215574427.

Scott, M., and Bruce, R. (1987), "Five stages of growth in small business", Long Range Planning, 20(3), pp. 45-52.

Shane, S. and Venkataraman, S., (2000), The promise of entrepreneurship as a field of research. Academy of management review, 25(1), pp.217-226.

Shamir, B. and Howell, J.M., (1999). Organizational and contextual influences on the emergence and effectiveness of charismatic leadership. The Leadership Quarterly, 10(2), pp.257-283.

Shrader, C. B., Mulford, C. L., and Blackburn, V. L. (1989), "Strategic and operational planning, uncertainty, and performance in small firms", Journal of Small Business Management, 27(4), 45.

Siddiqui, S. and Jan, S., (2017), "Developing Entrepreneurial Intensity among Women Entrepreneurs of Jammu and Kashmir: Model Building through Confirmatory Factor Analysis", Vision, 21(3), pp.295-304.

Siyanbola, W.O., Aderemi, H.O. and Egbetokun, M. S., (2011), "Framework for technological entrepreneurship development: key issues and policy directions", American Journal of Industrial and Business Management 1(1), pp. 10-19.

Sklaveniti, C, (2017), "Processes of entrepreneurial leadership: Co-acting creativity and direction in the emergence of new SME ventures", International Small Business Journal 35(2), pp. 197-213.

Skodvin, T. and Andresen, S. (2006), "Leadership revisited", Global Environmental Politics 6(3), pp. $13-27$. 
Simba and Thai (2018)

Journal of Small Business Management

Slack, N. and Lewis, M., (2008), Operations strategy. $2^{\text {nd }}$ Edition, John Wiley and Sons, Ltd. Prentice Hall: Financial Times, Essex, ISBN: 978-0-273-69519-6

Smallbone, D., Leigh, R. and North, D., (1995), "The characteristics and strategies of high growth firms", International Journal of Entrepreneurial Behaviour and Research, 1(3), pp. 44-62.

Strauss, A., and Corbin, J., (1998), Basics of Qualitative Research. Thousand Oaks: California.

Stefanovska, L., and Soluncevski, M., (2015), Challenges and problems in the process of strategic planning in micro, small and medium enterprises", International May Conference on Strategic Management - IMKSM2015 Book of Proceedings, 29-31 May 2015, Bor, Serbia, ISBN 978-866305-030-3.

Stevenson, H. H., and Jarillo, J. C. (1990), “A paradigm of entrepreneurship: Entrepreneurial management", Strategic Management Journal [Special issue], 11: 17-27.

Stinchcombe, A. L., (1965), "Social structures and organizations", In James G. March (ed.), Handbook of Organizations: 142-193. Chicago: Rand McNally.

Stokes, D. and Wilson, N., (2010), Small Business Management and Entrepreneurship, ${ }^{\text {th }}$ Edition, SOUTH-WESTERN, Cengage Learning EMEA, ISBN: 978-1-4080-1799-9.

Storey, D. J., (1994), Understanding the Small Business Sector, Routledge: London.

Tarabishy, A., Solomon, G., Fernald, Jr., L. W., and Sashkin, M., (2005), “The entrepreneurial leader's impact on the organization's performance in dynamic markets", Journal of Private Equity 8(4), pp. 20-29.

Thornberry, N., (2006), Lead Like an Entrepreneur: Keeping the Entrepreneurial Spirit Alive within the Corporation. Fairfield, PA: McGraw Hill.

Tidd, J. and Bessant, J., (2014), Strategic innovation management. John Wiley and Sons, New York. ISBN 9781118457238

Timmons, J. A, and Spinelli, S., (2009), New Venture Creation, Entrepreneurship for the 21 st Century, $8^{\text {th }}$ Edition, McGraw-Hill Higher Education, ISBN-13: 978-0-07-338155-8.

Timmons, J. A., (1978), "Characteristics and role demand of entrepreneurship", American Journal of Small Business 3(1), pp. 5-17.

Thomson, J. L., (2001), Strategic Management. 4th ed. London: Thomson-Learning.

Thompson, J. L., Scott, J, M, and Martins, F., (2014). Strategic management: awareness and change, $7^{\text {th }}$ Edition, Cengage Learning EMEA: Hampshire, ISBN-10-1473704723

USAID, (2007), Booklet of standardized small and medium enterprise definitions; Available at: http://pdf.usaid.gov/pdf docs/PNADM845.pdf, Accessed 11.11.2017

UNDP, (2004), Business development services how to guide. Bratislava Regional Centre United Nations Development Programme, Available at: http://www.pintoconsulting.de/Images/pdf/10 business dev services 2004.pdf, Accessed on 15.11.2017.

Vecchio, R. P., (2003), "Entrepreneurship and Leadership: Common Trends and Common Threads," Human Resource Management Review 13(2), pp. 303-327.

Venkataraman, S., (1997), "The distinctive domain of entrepreneurship research", Advances in entrepreneurship, firm emergence and growth, 3(1), pp.119-138.

Watson, W, Pavur, R., Cooper, D., Torres, J. N. L. (2011), "Managerial characteristics, operational observations, and small business performance: A comparison of US and Mexican ventures", International Journal of Intercultural Relations (2011), DOI: 10.1016/j.ijintrel.2010.12.003.

Wennekers, S., and Thurik, R. (1999). Linking entrepreneurship and economic growth. Small Business Economics, 13(1), 27-55.

Weston, S. (2013), Leadership: A Critical Context, $2^{\text {nd }}$ Edition, SAGE PUBLICATIONS, Washington DC. ISBN: 9781446269909.

Wilkinson, A., (1999), Employment relations in SMEs”, Employee relations, 21(3), pp. 206-217.

Wiklund, J., Patzelt, H., and Shepherd, D. A. (2009), "Building an integrative model of small business growth”, Small Business Economics, 32(4), 351-374. 
Simba and Thai (2018)

Journal of Small Business Management

Wynarczyk, P., Watson, R., Storey, D., Short, H. and Keasey, K. (1993), Managerial Labour Markets in SMEs, Routledge, London.

Yukl, G., (1999), "An evaluation of conceptual weaknesses in transformational and charismatic leadership theories", Leadership Quarterly, 10(2), pp. 285-305.

Yukl, G. and Chavez, C., (2002). Influence tactics and leader effectiveness. Leadership, pp.139165.

Yukl, G. (2012), 'Effective leadership behaviour: what we know and what questions need more attention', Academy of Management Perspectives, 26 (4), 66 - 85. 